MINERALOGIA, 42, No 1: 33-37 (2011)

DOI: 10.2478/V10002-011-0004-9

www.Mineralogia.pl

MineRALOGICAL Society of Poland

Polskie TOWARZYSTWO MINERALOgICZNE

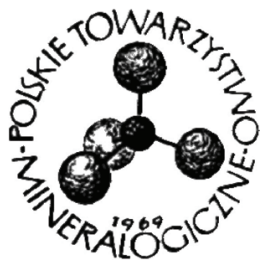

Original paper

\title{
Use of sulphur and carbon stable-isotope composition of fish scales and muscles to identify the origin of fish
}

\author{
Andrzej TREMBACZOWSKI ${ }^{1}$ \\ ${ }^{1}$ Mass Spectrometry Laboratory, Institute of Physics, Marie Curie-Sklodowska University \\ Maria Curie-Skłodowska Sq 1, 20-031 Lublin, Poland; \\ e-mail: andrzej.trembaczowski@poczta.umcs.lublin.pl
}

Received: October 30, 2010

Received in revised form: July 14, 2011

Accepted: March 10, 2012

Available online:, March 28, 2012

Abstract. $\delta^{34} \mathrm{~S}$ and $\delta^{13} \mathrm{C}$ analyses were used to determine the origin of trout specimens. The isotope record of their scales and muscles are compared with a database previously obtained from wild- and reared fish coming from Polish rivers and pond farms. The comparison made it possible to find out whether the trout were wild or reared.

Key-words: stable isotopes, $\delta^{34} \mathrm{~S}, \delta^{13} \mathrm{C}$, fish scales, fish muscle, food web relations

\section{Introduction}

Trout are among the most valuable fish for angling and for eating. Wild trout are protected and their catching is strongly limited. State laws restrict their capture to fishing with artificial baits. Anglers must also abide by seasonal-, size-, and number limits. During spawning any catching of fish is forbidden and, in some rivers sectors, fishing may be forbidden for all the times. For efficient protection, fish sold in shops also need to be under control. In this case, knowledge of the origin of sold fish can be important and, sometimes, methods for identifying the origin of fish can be required in order to exclude an illegal source. Isotope techniques can be very useful in this purpose.

Hobson (1999) points out the value of isotope analyses as a useful indicator for understanding the ecology of migratory animals and for recognising relations between food and animal tissues. The isotopic composition of animal tissue reflects diet. Fish scales, 
especially, contain an isotopic record of the whole life of a fish, while the muscles may inform about the last months. The isotopic composition of fish scales reflects the isotopic composition of the most common diet, which originates partly from river water (autochthonous diet) and partly outside the river (allochthonous diet). In large rivers autochthonous diet dominates while, in small streams, allochthonous diet is more significant. Reared fish differ very greatly in their isotopic composition compared to wild populations because they are fed commercial pellets (Dempson, Power 2004).

Research on fish ecology uses $\delta$-analyses to study: (1) food web relations (Hobson 1999; Fry 2002, 2006; Jardine et al. 2004; Hutchinson, Trueman 2006; Murchie, Power 2008; Solomon et al. 2008, Blanco et al. 2009), (2) fish migration, (3) to recognize fish origin (McCarthy, Waldron 2000; Dempson, Power 2004; Charles et al. 2004; Kennedy et al. 2004; Ciancio et al. 2005, 2008; Jardine et al. 2005a, b, Sinnatamby et al. 2008; Solomon et al. 2008) and (4) to distinguish anadromous and resident forms of salmonid species.

The results derived from the present study show the possible application of stable isotope techniques for identifying the origin of fish. Comparison of the $\mathrm{S}$ and $\mathrm{C}$ isotopic composition of fish scales extracted from wild- and reared fish with the isotopic record of trout (Salmo trutta m. fario) of unknown origin was the tool used to distinguish wild- from reared specimens. The wild fish (trout and grayling) used for comparison originated from the Polish rivers (SE Poland), the reared trout came from commercial pond farms and the specimens of sea trout, living in the Baltic Sea, were caught in Pomeranian rivers. Their isotopic composition and relationship between their isotopic record with different riverine conditions were studied previously (Trembaczowski, Niezgoda 2011). The trout of unknown origin were delivered by a guard of the fisheries of the Polish National Angling Association.

\section{Method}

Muscle and scale samples collected from two trout were analyzed for S and C isotopes. Samples were cleaned (washed in distilled water, rinsed with acetone) and dried in air at the temperature at $60^{\circ} \mathrm{C}$. The fish scales were washed with distilled water until they were clean. A small amount of $\mathrm{KOH}$ was added to remove other organic materials like slime or the remains of skin. Samples of dry muscle were homogenized with a mortar.

The amount of dry material needed for $\delta^{13} \mathrm{C}$ analysis was small (6-9 $\mathrm{mg}$ ), while the amount used for $\delta^{34} \mathrm{~S}$ analysis was larger $(300-1000 \mathrm{mg})$ due to low $\mathrm{S}$ concentration. The dry samples were combusted in a Parr bomb and the sulphur extracted as barium sulphate was converted to $\mathrm{SO}_{2}$ for $\delta^{34} \mathrm{~S}$ analysis in a vacuum line at $800^{\circ} \mathrm{C}$ (Halas, Szaran 2001, 2004). The samples used for $\delta^{13} \mathrm{C}$ analysis were combusted with $\mathrm{CuO}$ at the temperature at $560^{\circ} \mathrm{C}$ in sealed pyrex glass ampoules. Isotope analyses were performed with a dual-inlet system, triple-collector mass spectrometer. The $\delta^{34} \mathrm{~S}$ data are expressed relative to VCDT using NBS-127 as a standard and $\delta^{13} \mathrm{C}$ relative to PDB using NBS-22 and IA-R042 (powdered bovine liver). The standard uncertainty in all cases was $0.05 \%$. All samples were prepared and measured twice; no significant differences were found. 


\section{Results and discussion}

The scales and muscles of two adult trout were delivered to the laboratory to ascertain whether they were wild or reared. The fish, being sold during the spawning period, were confiscated by a guard. Although the seller assured that the trout came from a farm, it was suspected that they were wild fish illegally caught.

The isotope record of scales extracted from fish inhabiting different rivers reflect their distinct habitat conditions (nature of available diet), whereas the $\delta$-values of scales from reared trout reflect the isotopic composition of the pellets used for feeding (Dempson, Power 2004). This information may be key to determining whether the fish was wild or reared. Results of $\delta$-analyses are shown in Table 1 . These $\delta$-values may be compared with $\delta$-values obtained for wild and reared fish (trout and grayling) from Polish rivers (see Fig. 1).

TABLE 1

Sulphur and carbon isotopic composition of two trout of unknown origin.

\begin{tabular}{lll}
\hline$\delta$-values & Trout A & Trout B \\
\hline$\delta^{34} \mathrm{~S}(\%)$ scales & -2.27 & -2.08 \\
$\delta^{34} \mathrm{~S}(\%)$ muscles & +2.03 & -6.27 \\
$\delta^{13} \mathrm{C}(\%)$ scales & -22.24 & -23.35 \\
$\delta^{13} \mathrm{C}(\%)$ muscles & -26.84 & -26.22 \\
\hline
\end{tabular}

The values of $\delta^{34} \mathrm{~S}$ in trout scales from several Polish rivers range from: $-13 \%$ to $+7 \%$ and the $\delta^{13} \mathrm{C}$ values of the scales, from: $-31 \%$ to $-21 \%$ (Trembaczowski, Niezgoda 2011). This isotopic record reflects the diet of wild fish living in natural conditions. Reared trout, fed commercial pellet produced from fish meal, have a different isotopic composition. They are substantially enriched in the heavier sulphur isotope than are wild fish because the feed (pellet) is produced from sea fish. The $\delta^{34} \mathrm{~S}$ recorded in the scales of reared trout range from: $+11 \%$ to $+26 \%$. Compared to the wild fish, the reared trout also show enrichment in the heavier carbon isotope with $\delta^{13} \mathrm{C}$ ranging from: $-22 \%$ to $-19 \%$. Average values of $\delta^{34} \mathrm{~S}$ for the sampled reared trout are close to $+16 \%$ and average $\delta^{13} \mathrm{C}$ values, close to $-21 \%$. The $\delta^{34} \mathrm{~S}$ of a pellet sample is $+14.26 \%$, and the $\delta^{13} \mathrm{C},-22.92 \%$. 


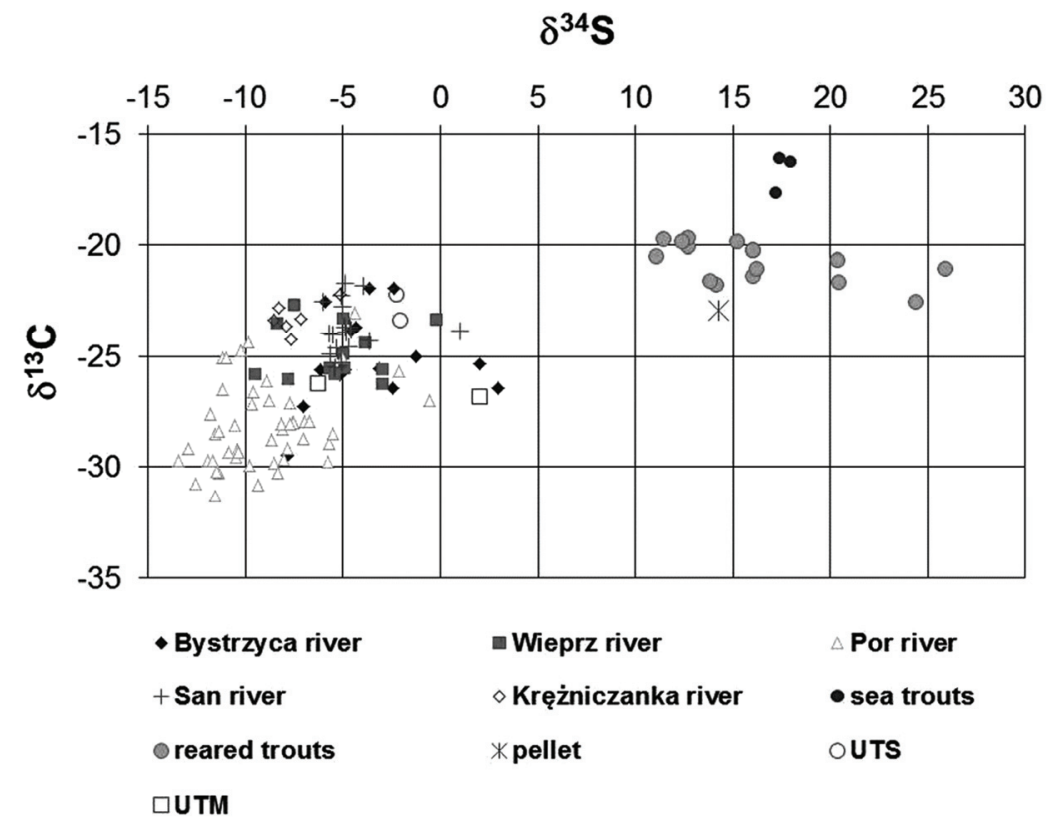

Fig. 1. The comparison of $\delta^{13} \mathrm{C}$ and $\delta^{34} \mathrm{~S}$ values extracted from trout of unknown origin (UTS - scale extract, UTM - muscle extract) on the background of the results of the earlier study (Trembaczowski, Niezgoda 2011).Wild trout and grayling originated from five rivers in SE Poland - Bystrzyca, Wieprz, Por, San, Krężniczanka.

\section{Conclusion}

This study has demonstrated that stable isotope $\delta$-values of analyzed trout of unknown origin are similar to those of wild fish living in natural conditions and that they differ considerably from those of trout that are fed artificial food. These two trout could not have entered the pond by passing through the grill from the river as young fish as, in that case, the isotopic composition of their tissues, scales and especially muscles, would have been changed during growth and both $\mathrm{S}$ and $\mathrm{C} \delta$-values would be higher than they are. On the other hand, adult trout could not have got into the pond through the grill. Our S and C $\delta$-analyses confirm that the trout had been taken from the river and had not been reared in ponds.

Acknowledgements. Special thanks are due to Ryszard Bąk of the Polish National Angling Association, for providing trout of unknown origin and to anonymous reviewers for helpful and constructive comments.

\section{References}

Blanco, A., Deudero, S., \& Box, A. (2009). Muscle and scale isotopic offset of three fish species in the Mediterranean Sea: Dentex dentex, Argyrosomus regius and Xyrichtys novacula. Rapid Communication Mass Spectrometry, 23(15), 2321-2328. 
Charles, K., Roussel, J.-M., \& Cunjak, R.A. (2004). Estimating the contribution of sympatric of anadromous and freshwater resident brown trout to juvenile production. Marine and Freshwater Research, 55(2), 185-191. DOI: 10.1071/MF03173.

Ciancio, J.E., Pascual, M.A., Lancelotti, J., Riva Rossi, C., \& Botto, F. (2005). Natural colonization and establishment of a Chinook salmon, Oncorchynchus tshawytscha, population in the Santa Cruz River, an Atlantic basin of Patagonia. Environmental Biology of Fishes, 74(2), 219-227.

Ciancio, J. E., Pascual, M. A., Botto, F., Amaya-Santi, M., O'Neal, S., Riva Rossi, C., \& Iribarne, O. (2008). Stable isotope profiles of partially migratory salmonid populations in Atlantic rivers of Patagonia. Journal of Fish Biology, 72(7), 1708-1719. DOI: 10.1111/j.1095-8649.2008.01846.x.

Dempson, J.B., \& Power, M. (2004). Use of stable isotopes to distinguish farmed from wild Atlantic salmon, Salmo salar. Ecology of Freshwater Fish, 13(3): 176-184. DOI: 10.1111/j.1600-0633.2004.00057.x.

Fry, B. (2002). Stable isotopic indicators of habitat use by Mississippi River fish. Journal of the North American Benthological Society, 21(4) 676-685.

Fry, B. (2006). Stable Isotope Ecology. New York: Springer.

Halas, S., \& Szaran, J. (2001). Improved thermal decomposition of sulfates to $\mathrm{SO}_{2}$ and mass spectrometric determination of $\delta^{34}$ S IAEA SO-5 and NBS-127 sulfate standards. Rapid communication Mass Spectrometry, 15(17), 1618-1620.

Halas, S., \& Szaran, J. (2004). Use of $\mathrm{Cu}_{2} \mathrm{O}-\mathrm{NaPO}_{3}$ mixtures for $\mathrm{SO}_{2}$ extraction from $\mathrm{BaSO}_{4}$ for sulfur isotope analysis. Isotopes in Environmental and Health Studies, 40(3), 229-231.

Hobson, K. A. (1999). Tracing origins and migration of wildlife using stable isotopes: a review. Oecologia, 120(3), 314-326.

Hutchinson, J. J., \& Trueman, C. N. (2006). Stable isotope analyses of collagen in fish scales: limitation set by scale architecture. Journal of Fish Biology, 69(6), 1874-1880. DOI:10.1111/j.1095-8649.2006.01234.x.

Jardine, T.D, Cartwright, D.F, Dietrich, J.P., \& Cunjak, R.A. (2005a). Resource use by salmonids in riverine, lacustrine and marine environments: Evidence from stable isotope analysis. Environmental Biology of Fishes, 73(3). 309-319.

Jardine, T.D., Gray, M.A., McWilliam, S.M., \& Cunjak, R.A. (2005b). Stable Isotope Variability in Tissues of Temperate Stream Fishes. Transactions of the American Fisheries Society, 134(5), 1103-1110. DOI: 10.1577/T04-124.1.

Kennedy, B.P., Chamberlain, C.P., Blum, J.D., Nislow, K.H., \& Folt, C.L. (2005). Comparing naturally occurring stable isotopes of nitrogen, carbon, and strontium as markers for the rearing locations of Atlantic salmon (Salmo salar) Canadian Journal of Fisheries and Aquatic Sciences, 62(1), 48-57.

McCarthy, I.D, \& Waldron, S. (2000). Identifying migratory Salmo trutta using carbon and nitrogen stable isotope ratios. Rapid Communications in Mass Spectrometry, 14(15), 1325-1331.

Murchie, K.J., \& Power, M. (2004). Growth- and feeding-related isotopic dilution and enrichment patterns in young yellow perch (Perca flavescens). Freshwater Biology, 49(1), 41-54.

Sinnatamby, R.N., Dempson, J.B., \& Power, M. (2008). A comparison of muscle- and scale-derived $\delta^{13} \mathrm{C}$ and $\delta^{15} \mathrm{~N}$ across three life-history stage of Atlantic salmon Salmo salar. Rapid Communication Mass Spectrometry, 22(18), 2773-2778.

Solomon, C.T., Carpenter, S.,R., Rusak, J.A., \& Zanden, J.V. (2008). Long-term variation in isotopic baselines and implications for estimating consumer trophic niches. Canadian Journal of Fisheries and Aquatic Sciences., 65(10), 2191-2200.

Trembaczowski, A., \& Niezgoda, H. (2011). Relationship between isotope composition of sulphur in sulphate dissolved in river water and sulphur extracted from fish scales, Isotopes in Environmental and Health Studies, 47(2), 189-213. 